\title{
Preface
}

It is a central claim of this book that twenty-first century 'modernization' should be defined in terms of the extent to which people can define themselves not by ethnicity, 'caste' or religion but by their sense of 'occupation'. Throughout history, many have done so, which is why surnames in many cultures refer to occupational titles originally held by long-forgotten ancestors. The names 'Smith' or 'Taylor' spring to mind in English. But many people have never had a chance to pursue an occupation; others have been obliged to pursue one that they would not have chosen themselves.

A second claim is that the era of 'industrial citizenship' - the 'embedded' phase of Polanyi's Great Transformation (Polanyi [1944] 2001) - has passed, although many of its institutional features are still struggling to survive. Now, in the aftermath of globalization - the 'disembedded' phase of the Global Transformation - we may see an era of 'occupational citizenship' taking shape. The key figures in the industrial citizenship era were the employer and employee. For much of the twentieth century social, economic and labour policy focused overwhelmingly on the employee, and his needs and aspirations. This served the interests of capitalism and the state very nicely. It was not appropriate then, and it is certainly not appropriate in the Global Transformation.

Most of us, consciously or latently, have a vision of the Good Life. It is usually a far cry from the life we actually live, or even pragmatically aspire to live, if only because our aspirations are constrained by the range of feasible options, our self-confidence and the way we expect the surrounding social institutions to evolve.

As social thinkers - and we all possess that talent, cowed or undeveloped as it usually is - we should encourage each other to contemplate what could be the Good Life in the future Good Society. In doing so, we should impose a 'veil of ignorance', recognizing that we do not know where we would be in the range of distributions of statuses in that Good Society. We should go further than that, and say that the desirable options to be considered should be based on a reduction in the inequalities in the world, so that we do not merely aspire to be among the tiny super-affluent elite who can do what they wish when they wish with no care for what happens beyond their elite circle and bundle of soft-toned privileges. And vitally, what is proposed must meet what is later called the Ecological Constraint Principle. The values of reproduction must be elevated to that end.

If we were to talk about how we would wish to live, and how we would wish our fellow citizens to live, we would soon come back to the great visionaries of human history. In the cultural sphere from which I come, that would lead to Thomas More with his Utopia, Tom Paine with The Rights of Man, William Morris with News from Nowhere, Karl Marx of the Grundrisse, Hannah Arendt with The Human Condition. Others would reach back to the great equivalents of their cultures.

If we could indulge in this mild utopianism, we would probably find a large number of social thinkers in broad agreement on an underlying vision of the Good Society. It would be egalitarian in some sense, and give a high priority to what Aristotle called 
civic friendship and conviviality. It would not be one in which the state set out to create mass happiness or constant euphoria. Work would consist largely of self-chosen activity, with individuals in control of their development, in a community of kindred spirits with enough checks and balances to limit exploitation and oppression of the vulnerable by the powerful, and to avoid stifling conformity. We would wonder how work should be organized, or rather how it could be both organized and not organized, achieving a fine balance between disciplined activity and creative freedom.

It is that mild utopianism that guides the book. The plan of it weaves three themes. After presenting basic concepts of labour, work and occupation in Chapter 1, Chapters 2 and 3 consider how fictitious labour decommodification was tried during Polanyi's Great Transformation and how labour recommodification occurred during globalization as a global labour market has emerged. Chapter 4 sketches how the global class structure has evolved under globalization. This introduces the two strata that will shape occupational citizenship, the precariat and proficians. Chapters 5 and 6 show how barriers to commodification have been weakened or dismantled, and Chapter 7 considers the powerful trend towards occupational licensing. Chapter 8, polemically, traces some of the social and labour consequences of the construction of the global market society. Chapter 9 sketches the sort of institutions and policies that could shape a future of occupational citizenship, and Chapter 10 suggests how basic income security would facilitate a richer working life.

By way of warning, I will indicate some conclusions. The first is that the labour decommodification pursued by social democrats during the twentieth century was mistaken. The second is that the 'libertarian paternalists', who came to prominence in the early years of the twenty-first century with some strong claims, are dangerous.

Issues of paternalism were addressed in an earlier book, Beyond the New Paternalism (Standing, 2002). Since then 'libertarian paternalism' has revealed itself as a child of globalization, a response to the bewilderment unleashed by a market society in which everything is commodified. Without giving a hint of realizing what they were doing, the two Chicago academics who have made their international name with this perspective, and who were advisers to Barack Obama in his presidential campaign, described their goal as the construction of an 'architecture of choice' (Thaler and Sunstein, 2008). It was Jeremy Bentham who in 1787 presented a societal model as an architecture of choice for the design of prisons (Bentham [1787] 1995). His panopticon figures strongly in this book, recognizing how it was deployed in the work of Michel Foucault and his followers. The modern 'panopticonists' are almost as frightening as Bentham.

The third conclusion is that an 'emancipatory egalitarianism' is needed to create the basis of occupational citizenship. Any egalitarian at the end of globalization owes it to fellow progressives to offer a politics of paradise, in which freedom is married to equality. There is no going back to 'labourism'. Accordingly, the final two chapters sketch the sort of policies and institutions needed for occupational citizenship. It is essential that these enhance the occupational prospects of the growing number of people who are in the precariat, those without occupational profiles and without security, often living an almost nomadic existence, often unable to obtain regular employment or not actually wanting what used to be called 'a steady job'. I did wish to include reference to the precariat in the title of the book, until my publisher, Edward Elgar, and Commissioning Editor Felicity Plester sensibly persuaded me to drop it. However, the precariat and their more fortunate brethren, the proficians, are the future. 
Chapter 9 makes much of the need to dismantle the trappings of labourism and turn instead to collaborative bargaining, occupational associations and work rights rather than 'labour rights'. This leads to the final theme, which has been dismissed by labourists for decades. I merely make a plea for those who believe in freedom, work and occupation to consider it as part of an egalitarian strategy and look at it afresh in the light of the evolving globalizing labour market.

For some years, I have argued for a basic income as a right of citizenship. Although some commentators still think this a strange idea it has had great and honourable advocates over the ages, including Thomas Paine, Bertrand Russell, several Nobel Prizewinning economists, and artists such as William Morris. As co-chair of BIEN (Basic Income Earth Network), I also argued that it would only become a mainstream policy once efforts at paternalism had been extended (and found wanting) and once it became part of an integrated progressive vision. Such a vision must combine equality and freedom.

The groups who were self-defined as progressives for much of the nineteenth and twentieth centuries typically emphasized equality while neglecting freedom. This left a vacuum, which was filled by the apostles of Friedrich Hayek, the Chicago School of law and economics and the libertarians. Social democracy was not against freedom, but it promoted what in this book is called 'labourism', which is unsustainable in the Global Transformation and which actually constrained liberty.

The writer of this book is inclined to call himself 'a peasant'. His family and friends regard this as an affectation, understandably given that he spends his life dealing with books, statistics, bureaucrats and electronic gadgets, in between drinking fine wine and enjoying the sight, sound, taste and touch of the fine things in life. Yet the peasant need not be the dull simpleton so beloved of caricature, a potato in a sack who mumbles uhs and ahs between the cowsheds. The peasant blends into the human and natural environment and takes in the senses of existence, uncontrolled by the dictates of consumerism or capital accumulation. This is not to idealize the peasant. That would be oafish sentimentality. What is good about the peasant is that life is varied and close to nature in its appreciation of time, space and the senses. Life is about working to reproduce and sustain the environment, and the peasant's security comes from the simplicities of human passions. That is certainly not enough. A modern peasant must have education, not schooling, and a sense of culture.

It is probably more accurate to think of oneself as an artisan, on a good day, and a journeyman on all days. One author said that all of us can be craftsmen, which he defined as being very good at doing one thing (Sennett, 2008). Perhaps that is placing the bar too high. Most of us cannot be great artists or craftsmen. Our best hope is to be reasonably good at several things. In that regard, we are in good company. That great artist, John Gielgud, said with impish false modesty, 'I am a journeyman; I try to make it a little better every night'. To be an artisan or a journeyman in today's world would not be a bad lot.

And so to my gratitude. All creative works are acts of plagiarism to some extent. One has argued with and learned from so many people that it is impossible to identify those to blame or thank for good or bad ideas. I have been extremely fortunate over the years to have interacted with some very fine people who have expertise on subjects covered by this book. I could not possibly give any order of precedence, and will merely thank them. 
Among many others, I would like to mention, in alphabetical order, Miriam Abu-Sharkh, Richard Anker, Sam Butler, Ian Gough, Michael Hopkins, Renana Jhabvala, Claus Offe, Philippe van Parijs, Gerry Rodgers and Eduardo Suplicy. I would also like to thank Felicity Plester for her patience and advice. I should not mention the names of those from the ILO who gave me useful comments; however, I am grateful to them. I would also like to thank Kari Polanyi Levitt, Marguerite Mendell and Ayşe Buğra for having invited me to give a keynote address to the Karl Polanyi Conference in Istanbul in 2005. Kari's prodding over the years has been much appreciated, and I know much more about her father as a result.

A very special thanks goes to my son Graeme, on whom I have tested out a number of the ideas contained in the book. Another special one goes to Frances. I am still counting the ways, although will not risk the question mark this time. All I will say is that her help was real work.

Guy Standing Ponte agli Stolli

November 2008

\section{A NOTE ON GENDER}

Although the author has used traditional and gender-specific occupational terms, such as 'craftsman', 'journeyman', 'middleman' and 'salaryman', throughout this book, these terms (and masculine pronouns) should be understood as referring to both men and women where appropriate. The same applies to feminine occupational terms, such as 'midwife', and feminine pronouns. 
Guy Standing - 9781849802376 